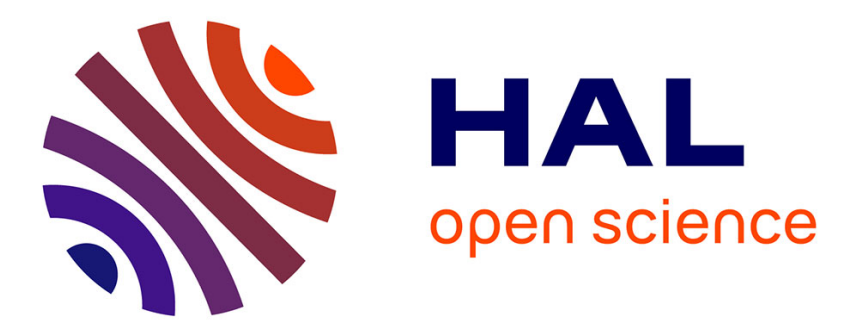

\title{
Proteomic analysis of glioblastomas: what is the best brain control sample?
}

\author{
Jean-Michel Lemée, Emmanuelle Com, Anne Clavreul, Tony Avril, Véronique \\ Quillien, Marie de Tayrac, Charles Pineau, Philippe Menei
}

\section{To cite this version:}

Jean-Michel Lemée, Emmanuelle Com, Anne Clavreul, Tony Avril, Véronique Quillien, et al.. Proteomic analysis of glioblastomas: what is the best brain control sample?. Journal of Proteomics, 2013, 85, pp.165-73. 10.1016/j.jprot.2013.04.031 . inserm-00871494

\section{HAL Id: inserm-00871494 https://www.hal.inserm.fr/inserm-00871494}

Submitted on 9 Oct 2013

HAL is a multi-disciplinary open access archive for the deposit and dissemination of scientific research documents, whether they are published or not. The documents may come from teaching and research institutions in France or abroad, or from public or private research centers.
L'archive ouverte pluridisciplinaire HAL, est destinée au dépôt et à la diffusion de documents scientifiques de niveau recherche, publiés ou non, émanant des établissements d'enseignement et de recherche français ou étrangers, des laboratoires publics ou privés. 


\section{Proteomic analysis of glioblastomas: what is the best brain control sample?}

Jean-Michel Lemée, M.D., ${ }^{1,2}$ Emmanuelle Com, Ph.D., ${ }^{3}$ Anne Clavreul, Ph.D., ${ }^{1,2}$ Tony Avril, Ph.D. ${ }^{4,5,6}$, Véronique Quillien, Ph.D. ${ }^{4,5,6}$, Marie de Tayrac, Ph.D. ${ }^{5,6,7}$, Charles Pineau, Ph.D. ${ }^{3}$, Philippe Menei, M.D., Ph.D. ${ }^{1,2}$

${ }^{1}$ Departement de Neurochirurgie, Centre Hospitalier Universitaire d'Angers, LUNAM université, 4 rue Larrey, 49100 Angers, France

${ }^{2}$ LUNAM Université, INSERM UMR-1066, Micro- et Nanomédecine Biomimétiques (MINT), 4 rue Larrey, 49100 Angers, France

${ }^{3}$ Proteomic Core Facility Biogenouest, IRSET, Inserm U1085, Campus de Beaulieu, 35042

Rennes, France

${ }^{4}$ Centre Eugène Marquis, Département de Biologie, 35042 Rennes, France

${ }^{5}$ CNRS, UMR 6290, Institut Génétique et Développement de Rennes, 35043 Rennes, France

${ }^{6}$ Université Rennes 1, UEB, IFR 140, Faculté de Médecine, 35043 Rennes, France

${ }^{7}$ CHU Rennes, Service de Génétique Moléculaire et Génomique, F-35033 Rennes, France

\section{Corresponding author:}

Jean-Michel Lemée, M.D.

Département de Neurochirurgie, CHU Angers

4 rue Larrey, 49933 Angers Cedex 09, France

Telephone: $0033241353988 \quad$ Fax: 0033241354508

Mail: lemee.jmichel@wanadoo.fr 


\section{Abstract}

Glioblastoma (GB) is the most frequent and aggressive tumor of the central nervous system. There is currently growing interest in proteomic studies of GB, particularly with the aim of identifying new prognostic or therapeutic response markers. However, comparisons between different proteomic analyzes of GB have revealed few common differentiated proteins. The types of control samples used to identify such proteins may in part explain the different results obtained.

We therefore tried to determine which control samples would be most suitable for GB proteomic studies. We used an isotope-coded protein labeling (ICPL) method followed by mass spectrometry to reveal and compare the protein patterns of two commonly used types of control sample: GB peritumoral brain zone samples (PBZ) from six patients and epilepsy surgery brain samples (EB) pooled from three patients. The data obtained were processed using AMEN software for network analysis.

We identified 197 non-redundant proteins and 35 of them were differentially expressed. Among these 35 differentially expressed proteins, six were over-expressed in PBZ and 29 in EB, showing different proteomic patterns between the two samples. Surprisingly, EB appeared to display a tumoral-like expression pattern in comparison to PBZ.

In our opinion, PBZ may be more appropriate control sample for GB proteomic analysis.

\section{Significance}

This manuscript describes an original study in which we used an isotope-coded protein labeling method followed by mass spectrometry to identify and compare the protein patterns in two types of sample commonly used as control for glioblastoma (GB) proteomic analysis: peritumoral brain zone and brain samples obtained during surgery for epilepsy. The choice of control samples is critical for identifying new pronostic and/or diagnostic markers in GB. 
Keywords:

Proteomic, glioblastoma, ICPL, epilepsy 


\section{$\underline{\text { Introduction }}$}

Glioblastoma (GB) is the most frequent and aggressive tumor of the central nervous system. Despite the development of new therapies, the prognosis remains poor, with a mean progressionfree survival of 7 months and an average survival of 12 to 15 months [1, 2]. Even following gross total resection and optimal adjuvant treatment, recurrence is extremely common, mainly from the margin of the resection cavity [3-5].

GB is a very hetererogenous groups of tumors [6], involving different zones; both genomic [7, 8] and proteomic [9-11] approaches have been used to study these tumors. These analyses led to the identification of different markers, allowing the characterization of different subtypes of GBs and tumoral mechanisms, and may serve as a basis for the development of new therapies focused on the molecular, genetic and proteomic particularities of GB.

In one of our previous proteomic studies, we used an isotope-coded protein label (ICPL) method to compare three areas of GB: the tumor zone (TZ), the interface zone between the tumor and the parenchyma (IZ) and the peritumoral brain zone (PBZ). We successfully identified 35 proteins over-expressed in the core of the tumor by comparison with the periphery and showed that 23 of these belong to a cohesive network of physically interacting proteins linked to several cellular functions [10].

However, few of the 35 proteins that we found to be altered in $\mathrm{TZ}$ are the same as those identified by previous studies (Table 1). For example, Khalil [12] used 2DE with MALDI-TOF MS and LCMS/MS to analyze $30 \mathrm{~GB}$ samples with seven control samples obtained from epilepsy surgery for reference. Forty-six differentially expressed proteins were identified of which only ten proteins were in common with our study ( $\beta$-actin, CKB, GDI1, ALDOA, 14-3-3 $\gamma$, ATP5A1, ALB, GFAP, NEFL, ENO1). Except for $\beta$-actin, most of these proteins showed a different pattern of expression to that described in this previous study. Indeed, we found these proteins to be over-expressed in TZ versus PBZ whereas Khalil [12] observed under-expression in GB samples versus control epilepsy samples. To understand the apparent differences in the protein expression patterns between the two 
studies, we conducted a bibliographical search for proteomic analyses of fresh brain tumor samples (reported in Table 1). This analysis revealed substantial heterogeneity in results associated with the different proteomic analysis techniques employed and the control tissues used. Indeed, differences in both the analytical methodologies and the control tissues used may explain the only weak similarities between proteomic patterns reported by the various studies.

Obviously, normal live brain samples are not available to be used as control samples under all circumstancies, and consequently the control samples commonly used in GB proteomic studies include brain tissue obtained during surgery for epilepsy (EB) or from the walls of the resection cavity during GB surgery (PBZ), with the informed consent of the patient.

However, it is unclear whether PBZ or EB brain samples, commonly used as controls, can be considered to be "normal" brain tissue, and therefore whether they are appropriate for proteomic comparisons and describing the differential proteomic expression pattern of brain tumors.

The aim of this study was to analyze and compare the protein expression patterns of these two control tissues (PBZ versus EB) using the ICPL proteomic method, and to determine which is the most suitable for use as control tissue for proteomic analyses of brain tumors.

\section{Materials and Methods}

\section{Clinical materials}

Six patients whose diagnosis of primary GB (WHO 2007 classification) was confirmed by a central committee of neuropathologists and three patients undergoing epilepsy surgery were included in the study. This study was approved by the relevant ethics committee (CPP Ouest II, Angers, France) and all patients signed an informed consent form for participation in this study.

The tumoral zone and PBZ from GB were defined on preoperative T1 gadolinium-enhanced 3D MRI. Stereotaxic biopsies were performed in the operating theater, by computer-assisted neurosurgery (BrainLab®, La Défense, France). EB was obtained from cortical resection during 


\begin{tabular}{|c|c|c|c|c|c|c|c|}
\hline Reference & Year & $\mathbf{n}$ & WHO grade & Method & Control & $\begin{array}{l}\text { Proteins } \\
\text { Differentially } \\
\text { expressed }\end{array}$ & $\begin{array}{l}\text { Proteins } \\
\text { in } \\
\text { common }\end{array}$ \\
\hline [27] & 2011 & 5 & GB & $\begin{array}{l}\text { 2DGE, MALDI-TOF } \\
\text { MS, 2D-PAGE, } \\
\text { Western Blot }\end{array}$ & EB & 22 & 4 \\
\hline [28] & 2009 & 27 & $\mathrm{~GB}$ & Western Blot & $\begin{array}{l}\text { Cancer genome } \\
\text { atlas }\end{array}$ & 55 & 1 \\
\hline [29] & 2009 & 1 & GB & HPLC-ESI-MS/MS & PBZ & 15 & - \\
\hline [30] & 2009 & 3 & $\mathrm{~GB}$ & $\begin{array}{l}\text { 2DGE, MALDI-TOF } \\
\text { MS }\end{array}$ & PBZ & 8 & 1 \\
\hline [12] & 2007 & 41 & $\begin{array}{l}24 \text { primary GBs } \\
4 \text { secondary GBs } \\
4 \text { grade III } \\
2 \text { grade II } \\
7 \text { epilepsy }\end{array}$ & $\begin{array}{l}\text { 2D-PAGE, 2DGE, } \\
\text { MALDI-TOF MS }\end{array}$ & EB & 91 & 9 \\
\hline [31] & 2007 & 20 & $\begin{array}{l}10 \mathrm{GBs} \\
10 \text { controls }\end{array}$ & $\begin{array}{l}\text { Nano-LC prior to } \\
\text { MALDI-TOF/TOF }\end{array}$ & $\begin{array}{l}\text { Samples from } \\
\text { different patients } \\
\text { with a variety of } \\
\text { CNS conditions }\end{array}$ & 16 & 0 \\
\hline [32] & 2005 & 20 & $\begin{array}{l}10 \text { grade IV } \\
10 \text { grade II }\end{array}$ & $\begin{array}{l}\text { 2DGE, } \\
\text { LC-ESI-MS/MS, } \\
\text { Western Blot }\end{array}$ & PBZ & 15 & 2 \\
\hline [33] & 2005 & 13 & GBs & 2DGE & PBZ & 19 & 1 \\
\hline [34] & 2005 & 127 & $\begin{array}{l}57 \text { GBs } \\
22 \text { grade III glioma } \\
29 \text { grade II glioma }\end{array}$ & MALDI-TOF & $\begin{array}{l}19 \text { patients } \\
\text { undergoing surgery } \\
\text { for "non-neoplastic } \\
\text { diseases" }\end{array}$ & 24 & 0 \\
\hline [35] & 2005 & 27 & $\begin{array}{l}10 \text { GBs } \\
14 \text { grade III } \\
1 \text { grade II } \\
2 \text { grade I }\end{array}$ & $\begin{array}{l}\text { 2DGE, MALDI-TOF } \\
\text { MS }\end{array}$ & EB & 29 & 4 \\
\hline$[36]$ & 2004 & 85 & $\begin{array}{l}52 \text { GBs } \\
13 \text { grade III } \\
10 \text { grade II } \\
10 \text { epilepsy }\end{array}$ & $\begin{array}{l}\text { 2DGE, MALDI-TOF } \\
\text { MS }\end{array}$ & PBZ & 37 & 2 \\
\hline [37] & 2004 & 18 & $\begin{array}{l}4 \text { GBs } \\
2 \text { oligo II } \\
2 \text { AO grade III } \\
2 \text { embryonal } \\
\text { carcinoma } \\
1 \text { pheochromocytoma } \\
1 \text { DNET } \\
1 \text { gemistocytic } \\
\text { astrocytoma grade II }\end{array}$ & MALDI-MS & $E B$ & $\begin{array}{l}\text { Identification } \\
\text { of protein } \\
\text { patterns } \\
\text { without } \\
\text { protein } \\
\text { characterizati } \\
\text { on }\end{array}$ & - \\
\hline [38] & 2003 & 5 & $\begin{array}{l}2 \text { GBs } \\
2 \text { grade III } \\
1 \text { grade I }\end{array}$ & $\begin{array}{l}\text { 2DGE, MALDI-TOF } \\
\text { MS }\end{array}$ & $\begin{array}{l}\text { PBZ from the same } \\
\text { patient }\end{array}$ & 15 & 1 \\
\hline [39] & 2003 & 4 & $4 \mathrm{GBs}$ & SELDI-TOF-MS & None & $\begin{array}{l}\text { Identification } \\
\text { of protein } \\
\text { profiles } \\
\text { without } \\
\text { protein } \\
\text { characterizati } \\
\text { on }\end{array}$ & - \\
\hline [40] & 2001 & 94 & $\begin{array}{l}56 \text { GBs } \\
13 \text { AAllI } \\
25 \text { low-grade gliomas }\end{array}$ & $\begin{array}{l}\text { Western Blot } \\
\text { analysis }\end{array}$ & $\begin{array}{l}\text { Lysates from } 16 \\
\text { week old fetuses }\end{array}$ & 14 & 0 \\
\hline
\end{tabular}

Table 1: Overview of the GB biopsy proteomic literature and comparison of the proteins identified with our previous study ${ }^{*}$ [10]

GB: glioblastoma; AA: anaplastic astrocytoma; AO: anaplastic oligodendroglioma; oligo: oligodendroglioma; DNET: Dysembryoplastic neuroepithelial tumor; 2DGE: 2D Gel electrophoresis; ICPL: isotope coded protein labelling; LCESI: liquid chromatography electrospray ionization; MALDI-TOF: matrix-assisted laser desorption ionization time of flight; nano-LC: nanoliquid chromatography; SELDI-TOF: surface enhanced laser desorption ionization time of flight; PBZ: peritumoral brain zone, EB: peripheral epilepsy surgery brain zone. 
surgery for epilepsy after identification of the epileptic cradle using per-operative electroencephalograms and electrostimulation.

Histological analysis and protein extraction were performed for each biopsy specimen. For histological analysis, formalin-fixed, paraffin-embedded sections of the biopsy specimens were stained with hematoxylin-phloxin-saffron.

\section{$\underline{\text { Tissue protein extraction }}$}

Protein extracts of tissue samples were prepared as previously described [10]. Briefly, cell pellets from $\mathrm{PBZ}$ and $\mathrm{EB}$ samples were resuspended in cold lysis buffer $(6 \mathrm{M}$ guanidine $\mathrm{HCl}, \mathrm{pH} 8.5$, cells/buffer: 1/2.5(v/v)) and sonicated on dry ice with an ultrasonic processor (Bioblock Scientific, Illkirch, France) six times for $10 \mathrm{sec}$ with $30 \mathrm{sec}$ pauses between using a microtip setting power level at $40 \%$ pulse duration. The homogenates were centrifuged $\left(15,000 \mathrm{~g}, 30 \mathrm{~min}, 4^{\circ} \mathrm{C}\right)$ and the resulting supernatants were then ultracentrifuged $\left(105,000 \mathrm{~g}, 1 \mathrm{~h}, 4^{\circ} \mathrm{C}\right)$. Protein concentrations in the resulting supernatants were measured with a BioRad Protein Assay Kit (BioRad, Marnes-laCoquette, France) according to the manufacturer's instructions. The samples from the three patients undergoing epilepsy surgery were pooled.

\section{$\underline{\text { ICPL labeling and protein digestion }}$}

The experimental design and the ICPL method are described in Table 2. ICPL labeling was performed on $50 \mu \mathrm{g}$ of PBZ or pooled EB samples as previously described (Com et al., 2012), according to the experimental design described in Table 2. Labeled proteins $(50 \mu \mathrm{g})$ were separated by SDS-PAGE in $12 \%$ precast gels (GeBeGel, Gene Bio Application), which was then stained with Coomasie blue R-350 using the EZBlue gel staining reagent (Sigma-Aldrich, Saint Quentin Fallavier, France). Entire gel lanes were cut into 20 sections, which were washed in different $\mathrm{ACN} / 100 \mathrm{mM} \mathrm{NH} \mathrm{NCO}_{3}$ solutions. In-gel digestion was performed overnight at $37^{\circ} \mathrm{C}$ with modified trypsin (Promega, Charbonnières-lès-Bains, France) following a previously described protocol (13). Proteolytic peptides were then extracted from the gel sections by sequential incubation in the following solutions: ACN/ $\mathrm{H}_{2} 0 / \mathrm{TFA}, 70: 30: 0,1$ (v/v/v), $100 \% \mathrm{ACN}$ and 
ACN/ $\mathrm{H}_{2}$ 0/TFA, 70:30:0,1 (v/v/v), and the extracts were concentrated by evaporation down to a final volume of $30 \mu \mathrm{L}$.

\begin{tabular}{lccc}
\hline & L & M & H \\
\hline Reaction 1 & EB pool & GB3-PBZ & GB16-PBZ \\
\hline Reaction 2 & GB10-PBZ & EB pool & GB25-PBZ \\
\hline Reaction 3 & GB22-PBZ & GB26-PBZ & EB pool \\
\hline
\end{tabular}

Table 2: Experimental design of the ICPL labelling for each sample

L: light ICPL reagent, M: medium ICPL reagent, H: heavy ICPL reagent, GB-PBZ: glioblastoma-peritumoral brain zone, EB pool: peripheral epilepsy surgery brain samples pooled from three patients.

\section{$\underline{\text { GLC-MS/MS analysis and protein identification and relative quantification }}$}

Proteolytic mixtures were analyzed on a nano-HPLC system (Ultimate 3000, Dionex, Jouy-enJosas, France) coupled on-line with an Esquire HCT Ultra PTM Discovery mass spectrometer (Bruker Daltonik GmbH, Bremen, Germany), equipped with a nanoflow ESI source and an ion trap analyzer (ITMS) as previously described [10]. The EsquireControl ${ }^{\mathrm{TM}}$ software (Bruker Daltonik $\mathrm{GmbH}$ ) automatically alterned MS and MS-MS acquisitions and was tuned to preferentially subject ICPL-labeled peptides to MS-MS acquisitions. DataAnalysis ${ }^{\text {TM }} 3.4$ software (Bruker Daltonik $\mathrm{GmbH}$ ) was used to create the peak lists from raw data. For each acquisition, a maximum of 700 compounds was detected with an intensity threshold of 100,000 and the charge state of precursor ions was automatically determined by resolved-isotope deconvolution. ProteinScape ${ }^{\mathrm{TM}} 2.0$ software (Bruker Daltonik GmbH) was used to submit MS/MS data to the Swiss-Prot database (version 70, November 2011, Homo Sapiens taxonomy, 20257 sequence entries) and the randomized version of this database (decoy) to determine the false positive rate (FPR), defined as the number of validated decoy hits / (number of validated targets hits + number of decoy hits) *100, using the Mascot algorithm (Mascot server v2.2, http://www.matrixscience.com) as previously described (Com et al., 2012). Given that modification of lysine residues by ICPL labeling prevents their cleavage by trypsin, arginine $\mathrm{C}$ was selected as the enzyme with one allowed miscleavage. Carbamidomethylation of cysteines was set as a fixed modification, and labeling of lysine residues 
by light (L), medium (M) or heavy (H) ICPL reagents, and methionine oxidation were considered as variable modifications. The mass tolerance for parent and fragment ions was set to 0.25 and $0.5 \mathrm{Da}$, respectively. Peptide identifications were accepted if the individual ion Mascot scores were above 30 or above the identity threshold (the ion score is $-10^{*} \log (\mathrm{p})$, where $\mathrm{p}$ is the probability that the observed match is a random event, p-value $<0.05$ ). The ProteinExtractor algorithm (14) was used to compile identified peptides to proteins as previously described [10]. Every protein reported was identified by at least one peptide with significant ion Mascot score (above the identity threshold) and which cannot be mapped to a higher-ranking protein already in the result list, and protein identifications were accepted if the FPR of the search was lower than $1 \%$.

WarpLC 1.2 software (Bruker Daltonik $\mathrm{GmbH}$ ) was used for relative protein quantification; this software automatically calculates $\mathrm{H} / \mathrm{L}, \mathrm{M} / \mathrm{L}$ and $\mathrm{H} / \mathrm{M}$ ratios by comparing the relative intensities of $\mathrm{m} / \mathrm{z}$ ratios corresponding to the labeled peptides observed on MS spectra using DataAnalysis 3.4 software using previously described parameters [10]. The minimum differences in H/L, M/L, and $\mathrm{H} / \mathrm{M}$ ratios associated with significant differences in protein expression were determined by calculating the technical variability of our system as previously described [10] and the significant threshold was fixed at 2 standard deviations from the normalized median of each H/L, M/L and $\mathrm{H} / \mathrm{M}$ ratio; this gavethresholds od 1.41 for over-expressed proteins and 0.71 for under-expressed proteins (data not shown).

\section{Gene ontology term enrichment and network analysis}

The Annotation, Mapping, Expression end Network (AMEN) suite of software tools (16) was used to assess biological process GO term enrichment in the GB-PBZ / EB differential protein group using the International Protein Index human proteome for reference (release 3.8) (20). To be significantly over-represented in a group of genes, a GO term should have a p-value (adjusted with FDR by the Benjamin-Hochberg Method) lower than 0.01 and at least three proteins had to be associated with the annotation involved. A high Ontology Specific Information Rate (OSIR) cutoff, $\geq 0.4$, was selected to avoid redundancy between closely related terms. 
The network representation was drawn using AMEN and seven protein interaction databases: IntAct (release 2010-03, http://www.ebi.ac.uk/intact), MINT (release 2010-03, http://160.80.34.4/mint/Welcome.do), BioGRID (release 2010-03, http://thebiogrid.org), DIP (release 2010-04, http://dip.doe-mbi.ucla.edu), HPRD (release 2010-04, http://www.hprd.org), CORUM (release 2010-04, http://mips.helmholtz-muenchen.de/genre/proj/corum), and MatrixDB (release 2010-04, http://matrixdb.ibcp.fr).

\section{$\underline{\text { Results and discussion }}$}

This study is, to our knowledge, the first to compare the proteomic profiles of peritumoral brain zone tissue from GB and brain tissue samples obtained after epilepsy surgery to assess which is the most suitable for use as control samples for proteomic studies of GB.

Macroscopically, PBZ samples are composed of a mixture of grey and white matters but the proportion of white matter is greater because of the usual localization of GB in the brain.. As GB is an highly infiltrative tumor, histological analysis of PBZ can show microsatelite tumors or isolated infiltrated GB cells. For all the samples included in this study, histological analysis indicated an infiltration of tumor cells in two PBZ samples only (between 5-10\%) (data not shown). However, this infiltration was too low to alter the genomic and proteomic profiles of PBZ. In fact, while array CGH analysis of TZ indicated gain of chromosome 7 and loss of chromosome 9 and 10, no such genomic aberrations were observed in corresponding PBZ (data not shown). As epileptic zone are usually cortical, EB samples are principally composed of grey matter with a small contingent of white matter. Consequently, these two types of brain tissue sample are divergent, with different cytoarchitectural organizations and containing different types of neural cells.

We used the ICPL technique to compare the proteomes of these two types of brain tissue sample because it allows high-throughput, quantitative proteome profiling in an acurate and reproducible manner for up to four different samples [13]. Unlike other MS-based differential proteomic approaches, this technique can be applied both to cell cultures and to tissue samples and provides 
information about protein isoforms $[14,15]$. The ICPL technique is is also informative about nondifferential proteins thanks to the simultaneous quantification and identification.

By querying the human Swiss-Prot database, we identified 197 non-redundant proteins with a score above the identity threshold and with a FDR $<1 \%$ (supplementary table 1 ). The numbers of identified and quantified proteins per patient are reported in Table 3.

\begin{tabular}{lccccc}
\hline & \multicolumn{5}{c}{ PBZ/EB } \\
\hline & $\begin{array}{c}\text { \# identified } \\
\text { proteins }^{\mathrm{b}}\end{array}$ & $\begin{array}{c}\text { \# quantified } \\
\text { proteins }^{\mathrm{c}}\end{array}$ & $<0.71^{\mathrm{d}}$ & $>0.71$ and $<1.41^{\mathrm{e}}$ & $>_{1.41^{\dagger}}$ \\
\hline GB3 $^{\mathrm{a}}$ & 145 & 72 & 42 & 19 & 11 \\
\hline $\mathrm{GB10}^{\mathrm{a}}$ & 123 & 58 & 36 & 10 & 12 \\
\hline $\mathrm{GB16}^{\mathrm{a}}$ & 145 & 72 & 22 & 40 & 10 \\
\hline $\mathrm{GB22}^{\mathrm{a}}$ & 116 & 55 & 36 & 11 & 8 \\
\hline GB25 $^{\mathrm{a}}$ & 123 & 58 & 34 & 12 & 12 \\
\hline GB26 $^{\text {a }}$ & 116 & 55 & 46 & 6 & 3 \\
\hline
\end{tabular}

Table 3: Number of identified and quantified proteins for each patient

${ }^{a}$ The anonymous designation of each patient is reported in the first column, ${ }^{b}$ Number of unique identified proteins, ${ }^{\mathrm{C}}$ Number of unique quantified proteins, ${ }^{d}$ Number of unique quantified proteins with a ratio $<0.71$ (expression decrease above $41 \%$ ), ${ }^{e}$ Number of unique quantified proteins with a ratio $>0.71$ and $<1.41$ (non modulated expression), ${ }^{\mathrm{f}}$ Number of unique quantified proteins with a ratio $>1.41$ (expression increase above $41 \%)$

To assess the differential expression of proteins between PBZ and EB samples, we selected proteins with an average ratio, in six analyzed patients, of $>1.41$ or $<0.71$, with individual ratios $>1.41$ or $<$ 0.71 in at least $3 / 6$ patients with a minimum of two peptides in at least $50 \%$ of the patients. On this basis, we identified 35 proteins the expression of which differed between PBZ and EB. Most of these proteins (29/35 proteins, or 83\%) were more weakly expressed in PBZ than EB, and only six were more strongly expressed (Table 4).

AMEN software was used to evaluate GO term enrichment. The over-represented biological functions ( $\mathrm{p}$-value $<0.01)$ in $\mathrm{EB}$ are associated with energy metabolism, nervous sytem development, synaptic transmission, cellular transport and protein folding and processing (Figure 1). We previously observed these biological functions as being up-regulated in GB biopsies by 
comparison with PBZ samples used for reference [10]. Furthermore, we identified a functional network including 21 of the 35 proteins differentially expressed between PBZ and EB (Figure 2).

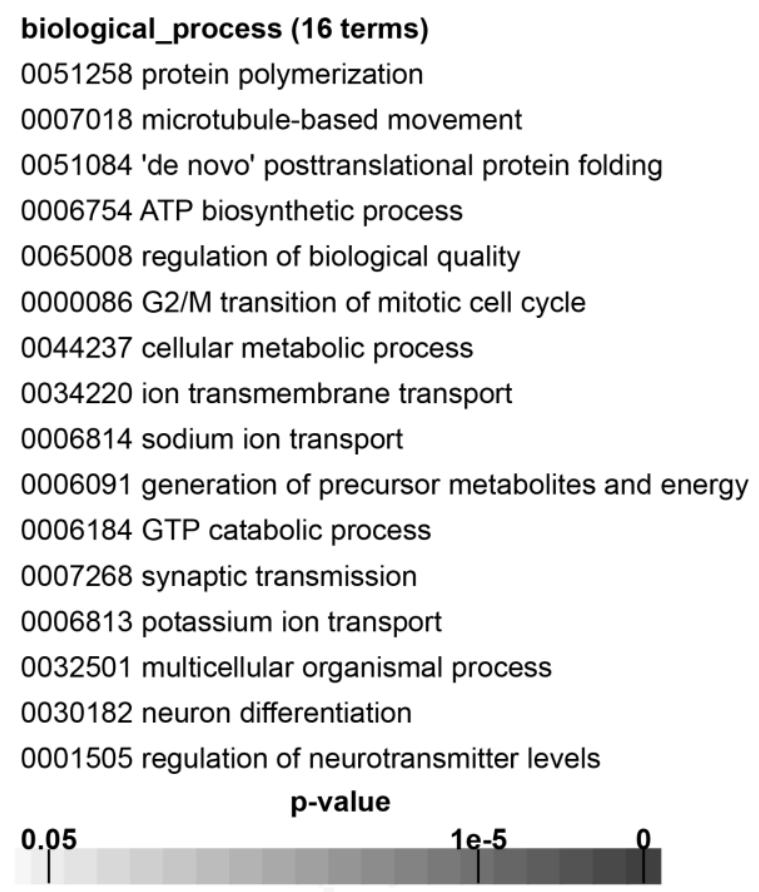

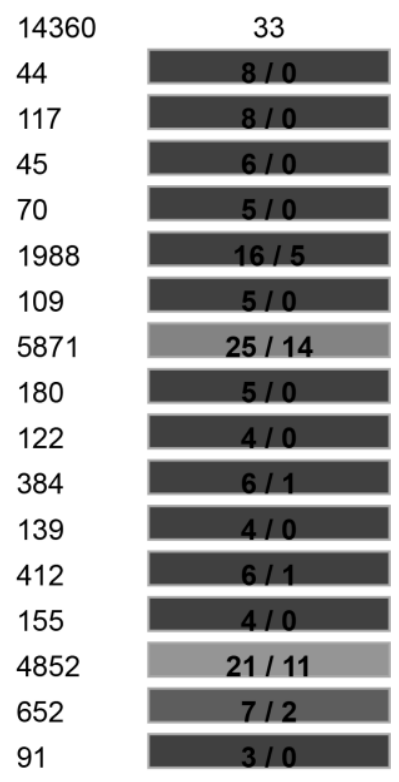

Figure 1: Biological processes involving the differentially expressed proteins

The color scale represents the down (in blue) or up-regulation (in red) with their respective corrected p-value for each GO term. Bold characters display a significant enrichment.

An analysis of the literature revealed that some of the six proteins up-regulated in GB-PBZ are ubiquitous, components of basic cellular pathways like DNA folding for histones (HIST1H2AC and HIST1H4A) or involved in the regulation of the osmotic pressure of blood, such as albumin. We will not consider these proteins further. The up-regulation of the myelin basic protein (MBP) and the glial fibrillary acidic protein (GFAP) observed in PBZ may be related to the fact that this zone contain more white matter than EB. . Note, however, that two of the up-regulated proteins, the crystallin B $\alpha$-chain (CRYAB) and the histone H3F3A have known oncogenic roles.

The histone H3F3A was not considered to be an oncogene until recently when two publications reported that it is a specific and reproducible marker of pontine GB [16, 17]. These articles document two mutations, K27M and G64V, in a large cohort of children with pediatric GB. They also report that the $\mathrm{K} 27 \mathrm{M}$ mutation is preferentially associated with cases with older onset, during 
teenage, and a hemispheric localization [16]. Therefore, the histone H3F3A up-regulation in GBPBZ/EB we observed is of interest. Possibly, this up-regulation could be the result of one of these mutations. Unfortunately, the tryptic peptides which would be mutated were not detected in our experiments.

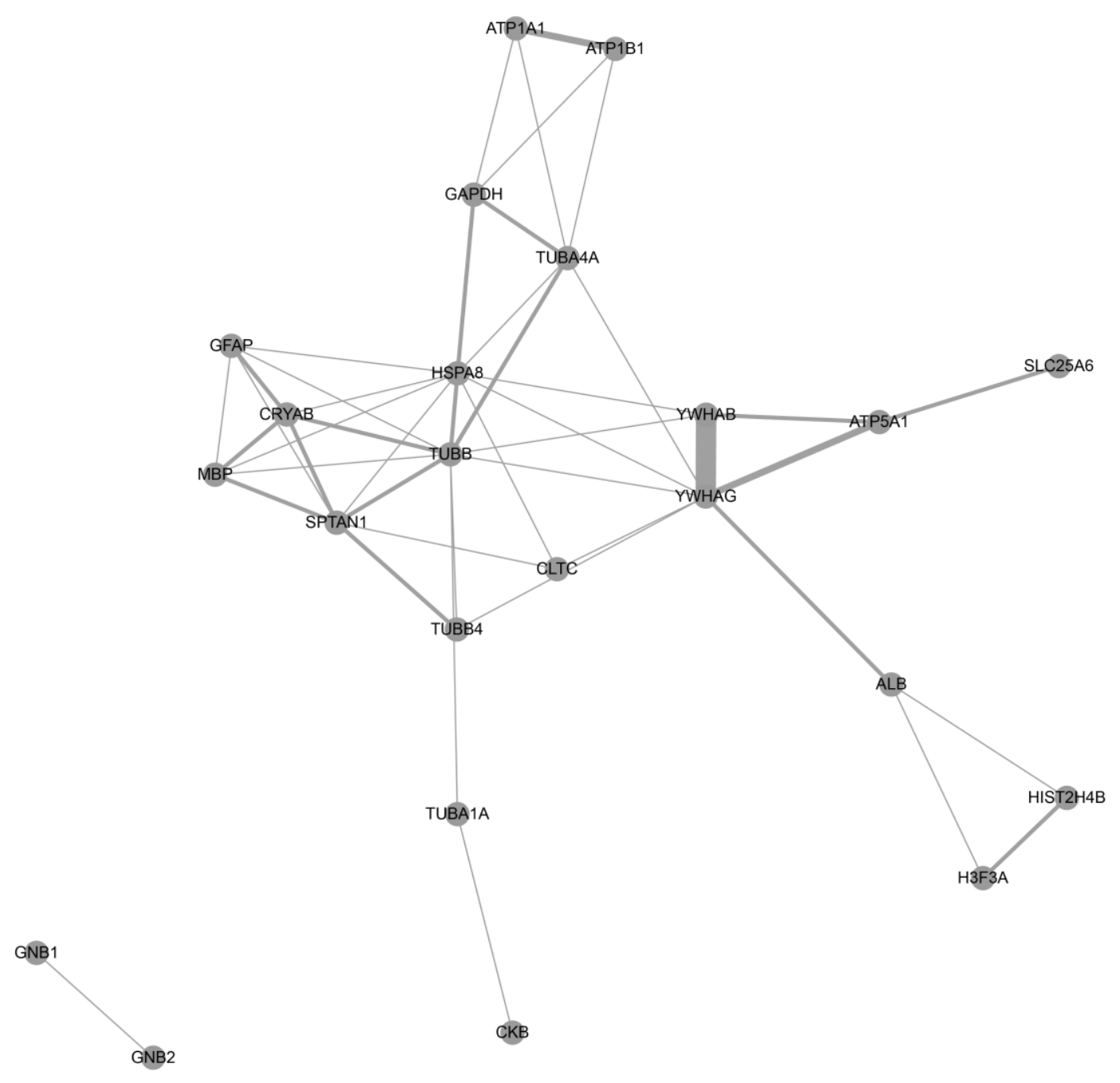

Figure 2: Interaction network representation of the differentially expressed proteins using the AMEN software

CRYAB is the major protein of the eye lens and also a chaperone belonging to the small heat shock protein family. In the CNS, CRYAB has a protective role in autoimmune demyelination [18]. CRYAB has been found in various types of solid tumor as a novel protein and may serve as a prognostic marker [19, 20]. CRYAB is also modulated by hypoxia [21, 22] and regulates tumor angiogenesis [23]. 
Our analysis of the literature for the 29 proteins up-regulted in EB versus PBZ indicated that only a few have a role in the pathogenesis of some forms of epilepsy: solute carrier family 25 member 6 (SCL25A6), Ras-related C3 botulinum toxin substrate 3 (Rac3), TUBA1A, spectrin alpha chain (SPTAN1) and GAPDH.

Surprisingly, we observed that several proteins over-expressed in EB have been implicated in the oncogenesis and in the pathophysological mechanisms of brain tumors; these proteins included 143-3 proteins $\beta$ and $\gamma$, the ATPase $\mathrm{Na}+\mathrm{K}+$ transporting alpha- 1 and alpha-2 polypeptides (ATP1A1 and ATP1A2), GAPDH, the heat shock $70 \mathrm{kDa}$ protein 8 (HSPA8), phosphatidylethanolamine binding protein 1 (PEBP1/RKIP) and the tubulin subtypes identified (TUBA1A, TUBA1B, TUBA4A, TUBAL3, TUBB, TUBB2A, TUBB3 and TUBB4).

These various findings demonstrate that the proteomes of PBZ and EB differ, but that EB has a more "tumoral" protein expression pattern, whereas PBZ seemed to have a more conventional proteomic profile. The up-regulation of oncogenic proteins such as Fos and Jun has already been observed in the dendate gyrus of animal models of epilepsy [24, 25]. Therefore, in our opinion, PBZ appears to be a more suitable control tissue than EB for proteomic studies of GB. However, considering PBZ as a "normal" tissue is likely to be erroneous. GB generally recurs at the resection margin, strongly suggesting that the PBZ is not "normal" [3-5]. Furthermore, we have isolated a new cell population from PBZ; these cells, named GB-associated stromal cells (GASCs), have properties similar to those of cancer-associated fibroblasts (CAFs). Like CAFs, GASCs express mesenchymal markers and have tumor-promoting effects [26].

Post-mortem brain tissue obtained from autopsy is a potential alternative source of brain control samples. However, Skold and collaborators [27] showed that several highly abundant proteins are enzymatically degraded in the brain within minute of death, such that the proteome rapidly differs from that normally present in vivo. 


\section{Up-regulated proteins}

CRYAB_HUMAN

H2A1C_HUMAN

H33_HUMAN

H4_HUMAN

ALBU_HUMAN

GFAP_HUMAN

MBP_HUMAN

Down-regulated proteins

PRDX2_HUMAN

ENOA_HUMAN

CLH1_HUMAN

DYN1_HUMAN

1433B_HUMAN

1433G_HUMAN

TBA4A_HUMAN

TBB3_HUMAN

PEBP1_HUMAN

TBB4_HUMAN

ADT3_HUMAN

RAC3_HUMAN

TBB5_HUMAN

TBA1A_HUMAN

TBA1B_HUMAN

TBB2A_HUMAN

GBB2_HUMAN

AT1A3_HUMAN

TBAL3_HUMAN

G3P_HUMAN

AT1A2_HUMAN

ATPA_HUMAN

HSP7C_HUMAN

SPTA2_HUMAN

AT1A1_HUMAN

GBB1 HUMAN

KCRB_HUMAN

AT1B1_HUMAN
Alpha-crystallin $B$ chain OS=Homo sapiens $G N=C R Y A B P E=1 S V=2$

Histone H2A type 1-C OS=Homo sapiens GN=HIST1H2AC PE=1 SV=3

Histone H3.3 OS=Homo sapiens GN=H3F3A PE=1 SV=2

Histone H4 OS=Homo sapiens GN=HIST1H4A PE=1 SV=2

Serum albumin precursor - Homo sapiens (Human)

Glial fibrillary acidic protein OS=Homo sapiens $\mathrm{GN}=\mathrm{GFAP} P E=1 \mathrm{SV}=1$

Myelin basic protein OS=Homo sapiens $G N=M B P P E=1 S V=3$

Peroxiredoxin-2 OS=Homo sapiens GN=PRDX2 PE=1 SV=5

Alpha-enolase - Homo sapiens (Human)

Clathrin heavy chain $1 \mathrm{OS}=$ Homo sapiens $\mathrm{GN}=\mathrm{CLTC} P E=1 \mathrm{SV}=5$

Dynamin-1 OS=Homo sapiens GN=DNM1 PE=1 SV=2

14-3-3 protein beta/alpha OS=Homo sapiens $G N=Y W H A B P E=1 S V=3$

14-3-3 protein gamma OS=Homo sapiens $\mathrm{GN}=\mathrm{YWHAG} P E=1 \mathrm{SV}=2$

Tubulin alpha- $4 A$ chain $O S=$ Homo sapiens $G N=T U B A 4 A P E=1 S V=1$

Tubulin beta- 3 chain OS=Homo sapiens GN=TUBB3 PE=1SV=2

Phosphatidylethanolamine-binding protein 1 - Homo sapiens (Human)

Tubulin beta- 4 chain $\mathrm{OS}=$ Homo sapiens $\mathrm{GN}=\mathrm{TUBB} 4 \mathrm{PE}=1 \mathrm{SV}=2$

ADP/ATP translocase $3 \mathrm{OS}=$ Homo sapiens $\mathrm{GN}=\mathrm{SLC} 25 \mathrm{~A} 6 \mathrm{PE}=1 \mathrm{SV}=4$

Ras-related $\mathrm{C} 3$ botulinum toxin substrate $3 \mathrm{OS}=$ Homo sapiens $\mathrm{GN}=\mathrm{RAC} 3 \mathrm{PE}=1 \mathrm{SV}=1$

Tubulin beta chain $\mathrm{OS}=$ Homo sapiens $\mathrm{GN}=\mathrm{TUBB} P E=1 \mathrm{SV}=2$

Tubulin alpha- $1 \mathrm{~A}$ chain $\mathrm{OS}=$ Homo sapiens $\mathrm{GN}=\mathrm{TUBA} 1 \mathrm{~A} P E=1 \mathrm{SV}=1$

Tubulin alpha- $1 B$ chain $O S=H o m o$ sapiens $G N=T U B A 1 B P E=1 S V=1$

Tubulin beta-2A chain OS=Homo sapiens $\mathrm{GN}=\mathrm{TUBB} 2 \mathrm{~A} P \mathrm{PE}=1 \mathrm{SV}=1$

Guanine nucleotide-binding protein $\mathrm{G}(\mathrm{I}) / \mathrm{G}(\mathrm{S}) / \mathrm{G}(\mathrm{T})$ subunit beta-2 OS=Homo sapiens $\mathrm{GN}=\mathrm{GNB} 2 \mathrm{PE}=1 \mathrm{SV}=3$

Sodium/potassium-transporting ATPase subunit alpha-3 OS=Homo sapiens GN=ATP1A3 PE=1 SV=3

Tubulin alpha chain-like 3 OS=Homo sapiens GN=TUBAL3 PE=1 SV=2

Glyceraldehyde-3-phosphate dehydrogenase - Homo sapiens (Human)

Sodium/potassium-transporting ATPase subunit alpha-2 OS=Homo sapiens GN=ATP1A2 PE=1 SV=1

ATP synthase subunit alpha, mitochondrial precursor - Homo sapiens (Human)

Heat shock cognate $71 \mathrm{kDa}$ protein $\mathrm{OS}=$ Homo sapiens $\mathrm{GN}=\mathrm{HSPA} 8 \mathrm{PE}=1 \mathrm{SV}=1$

Spectrin alpha chain, brain - Homo sapiens (Human)

Sodium/potassium-transporting ATPase subunit alpha-1 OS=Homo sapiens GN=ATP1A1 PE=1 SV=1

Guanine nucleotide-binding protein $\mathrm{G}(\mathrm{I}) / \mathrm{G}(\mathrm{S}) / \mathrm{G}(\mathrm{T})$ subunit beta-1 $\mathrm{OS}=$ Homo sapiens $\mathrm{GN}=\mathrm{GNB} 1 \mathrm{PE}=1 \mathrm{SV}=3$

Creatine kinase B-type $\mathrm{OS}=$ Homo sapiens $\mathrm{GN}=\mathrm{CKB} P E=1 \mathrm{SV}=1$

Sodium/potassium-transporting ATPase subunit beta- $1 \mathrm{OS}=$ Homo sapiens GN=ATP1B1 PE=1 SV=1 ratio ${ }^{\mathrm{c}}$

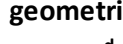

mean $^{\text {d }}$

$\%$ ratio

r $<0,71$ / \# quantified

patient

peptide ${ }^{\mathrm{g}}$

$4 / 6$

$50 \%$

2,45

2,43

0,34

$4 / 6$

$3 / 6$
$4 / 6$

$4 / 6$

$4 / 6$

$4 / 6$

$4 / 6$

$3 / 6$

$50 \%$

$0 \%$

$0 \%$

$0 \%$

1,70
1,27

$3 / 6$

0,81

0,71

0,66

0,66

0,58

0,58

0,57

0,56

0,56

0,56

0,55

0,54

0,54

0,54
0,53

0,53

0,51
0,50

0,50

0,50
0,48

0,48

0,47

0,46

0,46

0,45

0,44

0,43

0,42
0,30$$
\begin{aligned}
& 0,56 \\
& 0,41
\end{aligned}
$$$$
\begin{aligned}
& 0,41 \\
& 0,26
\end{aligned}
$$$$
0,43
$$$$
\begin{aligned}
& 0,43 \\
& 0,50
\end{aligned}
$$$$
0,37
$$$$
0,40
$$$$
0,24
$$$$
0,36
$$$$
0,35
$$$$
0,42
$$$$
0,39
$$$$
0,54
$$$$
0,54
$$$$
\begin{aligned}
& 0,54 \\
& 0,39
\end{aligned}
$$$$
0,39
$$ 
Table 4: Selection of proteins differentially expressed between PBZ and EB samples.

${ }^{a}$ Swiss-Prot accession number, ${ }^{\mathrm{b}}$ Protein name, ${ }^{\mathrm{c}}$ Number of observed ratios, ${ }^{\mathrm{d}}$ Geometric mean of the observed ratios, ${ }^{\mathrm{e}}$ Coefficient of variation of the observed ratios, ${ }^{\mathrm{f}}$ Number of patient ratio $>1.41$ or $<0,71$ compared to the total number of analyzed patient, ${ }^{g}$ Percentage of ratio quantified with more than one peptide 


\section{Conclusion}

The PBZ and EB have each a specific protein expression pattern. This has consequences for the interpretation of proteomic data obtained using these types of tissues as control samples. In our opinion, PBZ may be more suitable control tissue for differential proteomic analysis. However, this tissue should not be considered to be "normal" tissue and other alternatives should be sought.

\section{$\underline{\text { Acknowledgements }}$}

We gratefully acknowledge the contribution of the Cancéropole Grand Ouest. We also thank neurosurgeons at the CHU of Angers, Rennes and Tours for supplying peritumoral and epilepsy tissue samples. This work was supported by the French National Cancer Institute (INCa) and the Ligue Départementale de lutte contre le cancer.

\section{$\underline{\text { References }}$}

[1] Stupp R, Hegi ME, Mason WP, van den Bent MJ, Taphoorn MJ, Janzer RC, et al. Effects of radiotherapy with concomitant and adjuvant temozolomide versus radiotherapy alone on survival in glioblastoma in a randomised phase III study: 5-year analysis of the EORTC-NCIC trial. Lancet Oncol 2009;10:459-66.

[2] Wen PY, Kesari S. Malignant gliomas in adults. N Engl J Med 2008;359:492-507.

[3] Giese A, Kucinski T, Knopp U, Goldbrunner R, Hamel W, Mehdorn HM, et al. Pattern of recurrence following local chemotherapy with biodegradable carmustine (BCNU) implants in patients with glioblastoma. J Neurooncol 2004;66:351-60.

[4] Lefranc F, Brotchi J, Kiss R. Possible future issues in the treatment of glioblastomas: special emphasis on cell migration and the resistance of migrating glioblastoma cells to apoptosis. J Clin Oncol 2005;23:2411-22. 
[5] Liang BC, Thornton AF, Jr., Sandler HM, Greenberg HS. Malignant astrocytomas: focal tumor recurrence after focal external beam radiation therapy. J Neurosurg 1991;75:559-63.

[6] Iacob G, Dinca EB. Current data and strategy in glioblastoma multiforme. J Med Life 2009;2:386-93.

[7] Parsons DW, Jones S, Zhang X, Lin JC, Leary RJ, Angenendt P, et al. An integrated genomic analysis of human glioblastoma multiforme. Science 2008;321:1807-12.

[8] Vitucci M, Hayes DN, Miller CR. Gene expression profiling of gliomas: merging genomic and histopathological classification for personalised therapy. Br J Cancer 2011;104:545-53.

[9] Carlsson A, Persson O, Ingvarsson J, Widegren B, Salford L, Borrebaeck CA, et al. Plasma proteome profiling reveals biomarker patterns associated with prognosis and therapy selection in glioblastoma multiforme patients. Proteomics Clin Appl 2010;4:591-602.

[10] Com E, Clavreul A, Lagarrigue M, Michalak S, Menei P, Pineau C. Quantitative proteomic Isotope-Coded Protein Label (ICPL) analysis reveals alteration of several functional processes in the glioblastoma. J Proteomics 2012;75:3898-913.

[11] Niclou SP, Fack F, Rajcevic U. Glioma proteomics: status and perspectives. J Proteomics 2010;73:1823-38.

[12] Khalil AA. Biomarker discovery: a proteomic approach for brain cancer profiling. Cancer Sci 2007;98:201-13.

[13] Schmidt A, Kellermann J, Lottspeich F. A novel strategy for quantitative proteomics using isotope-coded protein labels. Proteomics 2005;5:4-15.

[14] Kellermann J. ICPL--isotope-coded protein label. Methods Mol Biol 2008;424:113-23.

[15] Lottspeich F, Kellermann J. ICPL labeling strategies for proteome research. Methods Mol Biol 2011;753:55-64.

[16] Schwartzentruber J, Korshunov A, Liu XY, Jones DT, Pfaff E, Jacob K, et al. Driver mutations in histone $\mathrm{H} 3.3$ and chromatin remodelling genes in paediatric glioblastoma. Nature 2012;482:226-31. 
[17] Sturm D, Witt H, Hovestadt V, Khuong-Quang DA, Jones DT, Konermann C, et al. Hotspot mutations in H3F3A and IDH1 define distinct epigenetic and biological subgroups of glioblastoma. Cancer Cell 2012;22:425-37.

[18] Ousman SS, Tomooka BH, van Noort JM, Wawrousek EF, O'Connor KC, Hafler DA, et al. Protective and therapeutic role for alphaB-crystallin in autoimmune demyelination. Nature 2007;448:474-9.

[19] Sorlie T, Perou CM, Tibshirani R, Aas T, Geisler S, Johnsen H, et al. Gene expression patterns of breast carcinomas distinguish tumor subclasses with clinical implications. Proc Natl Acad Sci U S A 2001;98:10869-74.

[20] Chin D, Boyle GM, Williams RM, Ferguson K, Pandeya N, Pedley J, et al. Alpha Bcrystallin, a new independent marker for poor prognosis in head and neck cancer. Laryngoscope 2005;115:1239-42.

[21] Yaung J, Kannan R, Wawrousek EF, Spee C, Sreekumar PG, Hinton DR. Exacerbation of retinal degeneration in the absence of alpha crystallins in an in vivo model of chemically induced hypoxia. Exp Eye Res 2008;86:355-65.

[22] Louapre P, Grongnet JF, Tanguay RM, David JC. Effects of hypoxia on stress proteins in the piglet heart at birth. Cell Stress Chaperones 2005;10:17-23.

[23] Dimberg A, Rylova S, Dieterich LC, Olsson AK, Schiller P, Wikner C, et al. alphaBcrystallin promotes tumor angiogenesis by increasing vascular survival during tube morphogenesis. Blood 2008;111:2015-23.

[24] Han SR, Shin C, Park S, Rhyu S, Park J, Kim YI. Differential expression of activating transcription factor-2 and c-Jun in the immature and adult rat hippocampus following lithiumpilocarpine induced status epilepticus. Yonsei Med J 2009;50:200-5.

[25] Houser CR, Zhang N, Peng Z, Huang CS, Cetina Y. Neuroanatomical clues to altered neuronal activity in epilepsy: from ultrastructure to signaling pathways of dentate granule cells. Epilepsia 2012;53 Suppl 1:67-77. 
[26] Clavreul A, Etcheverry A, Chassevent A, Quillien V, Avril T, Jourdan ML, et al. Isolation of a new cell population in the glioblastoma microenvironment. J Neurooncol 2012;106:493-504.

[27] Skold K, Svensson M, Norrman M, Sjogren B, Svenningsson P, Andren PE. The significance of biochemical and molecular sample integrity in brain proteomics and peptidomics: stathmin 2-20 and peptides as sample quality indicators. Proteomics 2007;7:4445-56.

[28] Collet B, Guitton N, Saikali S, Avril T, Pineau C, Hamlat A, et al. Differential analysis of glioblastoma multiforme proteome by a 2D-DIGE approach. Proteome Sci 2011;9:16.

[29] Brennan C, Momota H, Hambardzumyan D, Ozawa T, Tandon A, Pedraza A, et al. Glioblastoma subclasses can be defined by activity among signal transduction pathways and associated genomic alterations. PLoS One 2009;4:e7752.

[30] Melchior K, Tholey A, Heisel S, Keller A, Lenhof HP, Meese E, et al. Proteomic study of human glioblastoma multiforme tissue employing complementary two-dimensional liquid chromatography- and mass spectrometry-based approaches. J Proteome Res 2009;8:4604-14.

[31] Park CK, Jung JH, Moon MJ, Kim YY, Kim JH, Park SH, et al. Tissue expression of manganese superoxide dismutase is a candidate prognostic marker for glioblastoma. Oncology 2009;77:178-81.

[32] Mustafa DA, Burgers PC, Dekker LJ, Charif H, Titulaer MK, Smitt PA, et al. Identification of glioma neovascularization-related proteins by using MALDI-FTMS and nano-LC fractionation to microdissected tumor vessels. Mol Cell Proteomics 2007;6:1147-57.

[33] Odreman F, Vindigni M, Gonzales ML, Niccolini B, Candiano G, Zanotti B, et al. Proteomic studies on low- and high-grade human brain astrocytomas. J Proteome Res 2005;4:698708.

[34] Furuta M, Weil RJ, Vortmeyer AO, Huang S, Lei J, Huang TN, et al. Protein patterns and proteins that identify subtypes of glioblastoma multiforme. Oncogene 2004;23:6806-14. 
[35] Schwartz SA, Weil RJ, Thompson RC, Shyr Y, Moore JH, Toms SA, et al. Proteomic-based prognosis of brain tumor patients using direct-tissue matrix-assisted laser desorption ionization mass spectrometry. Cancer Res 2005;65:7674-81.

[36] Chumbalkar VC, Subhashini C, Dhople VM, Sundaram CS, Jagannadham MV, Kumar KN, et al. Differential protein expression in human gliomas and molecular insights. Proteomics 2005;5:1167-77.

[37] Iwadate Y, Sakaida T, Hiwasa T, Nagai Y, Ishikura H, Takiguchi M, et al. Molecular classification and survival prediction in human gliomas based on proteome analysis. Cancer Res 2004;64:2496-501.

[38] Schwartz SA, Weil RJ, Johnson MD, Toms SA, Caprioli RM. Protein profiling in brain tumors using mass spectrometry: feasibility of a new technique for the analysis of protein expression. Clin Cancer Res 2004;10:981-7.

[39] Hiratsuka M, Inoue T, Toda T, Kimura N, Shirayoshi Y, Kamitani H, et al. Proteomicsbased identification of differentially expressed genes in human gliomas: down-regulation of SIRT2 gene. Biochem Biophys Res Commun 2003;309:558-66.

[40] Hobbs SK, Shi G, Homer R, Harsh G, Atlas SW, Bednarski MD. Magnetic resonance image-guided proteomics of human glioblastoma multiforme. J Magn Reson Imaging 2003;18:5306.

[41] Chakravarti A, Delaney MA, Noll E, Black PM, Loeffler JS, Muzikansky A, et al. Prognostic and pathologic significance of quantitative protein expression profiling in human gliomas. Clin Cancer Res 2001;7:2387-95. 